\title{
Comparative effectiveness of two popular weight loss programs in women I: body composition and resting energy expenditure
}

\author{
Michelle Mardock*, Brittanie Lockard, Jonathan Oliver, Mike Byrd, Sunday Simbo, Andrew Jagim, Julie Kresta, \\ Claire Baetge, Peter Jung, Majid Koozehchian, Deepesch Khanna, Mike Greenwood, Chris Rasmussen, \\ Richard Kreider
}

From International Society of Sports Nutrition: 8th Annual ISSN Conference and Expo Las Vegas, NV, USA. 24-25 June 2011

\section{Background}

A number of commercial diet and exercise programs are promoted to help people lose weight and improve fitness. However, few studies have compared the effects of following different types of exercise and diet interventions on weight loss. The purpose of this study was to compare the efficacy of a more structured meal plan based diet intervention and supervised exercise program to a traditional point based diet program with weekly counseling and encouragement to exercise.

\section{Methods}

Fifty-one sedentary women $(35 \pm 8$ yrs, $163 \pm 7 \mathrm{~cm} ; 90 \pm 14 \mathrm{~kg}$; $47 \pm 7 \%$ body fat, $34 \pm 5 \mathrm{~kg} / \mathrm{m}^{2}$ ) were randomized to participate in the Curves $(C)$ or Weight Watchers (W) weight loss programs for 16-wks. Participants in the $\mathrm{C}$ program were instructed to follow a $1,200 \mathrm{kcal} / \mathrm{d}$ diet for 1 -week, $1,500 \mathrm{kcal} / \mathrm{d}$ diet for 3 weeks, and 2,000 kcals/d diet for 2weeks consisting of $30 \%$ carbohydrate, $45 \%$ protein, and $30 \%$ fat. Subjects then repeated this diet. Subjects also participated in the Curves circuit style resistance training program 3 days/week and were encouraged to walk at brisk pace for 30-min on non-training days. This program involved performing 30-60 seconds of bi-directional hydraulic-based resistance-exercise on 13 machines interspersed with 30-60 seconds of low-impact callisthenic or Zumba dance exercise. Participants in the $\mathrm{W}$ group followed the W point-based diet program, received weekly counseling at a local W facility, and were encouraged to

Exercise \& Sport Nutrition Lab. Texas A\&M University, College Station, TX 77843, USA increase physical activity. Dietary records, the International Physical Activity Questionnaire (IPAQ), dual energy X-ray absorptiometer (DEXA) determined body composition, and fasted resting energy expenditure (REE) measurements were obtained at $0,4,10, \& 16$ weeks and analyzed by multivariate analysis of variance (MANOVA) with repeated measures. Data are presented as changes from baseline for the $\mathrm{C}$ and $\mathrm{W}$ groups, respectively, after 4,10 , and 16 weeks.

\section{Results}

Participants in the $\mathrm{W}$ group reported a greater reduction energy intake (C $-270 \pm 450,-364 \pm 443,-386 \pm 480$; W $\left.636 \pm 510,-610 \pm 524,-549 \pm 522 \mathrm{kcals} / \mathrm{d}, \mathrm{p}_{q}=0.008\right)$ from baseline levels (C 1,693 \pm 430 ; W 1,954 $\pm 524 \mathrm{kcals} / \mathrm{d}$ ) with carbohydrate intake higher $(19.6 \pm 11$ grams/d, $6.0 \pm 1.9 \%)$ and protein intake lower $(-14.4 \pm 4$ grams $/ \mathrm{d},-4.2 \pm 1 \%)$ in the $\mathrm{W}$ group. Changes in group mean IPAQ walking (241 $\pm 366 \mathrm{MET}-\mathrm{min} / \mathrm{wk}, \mathrm{p}=0.50)$, moderate PA $(177 \pm 347 \mathrm{MET}-\mathrm{min} / \mathrm{wk}, \mathrm{p}=0.61)$, vigorous PA $(502 \pm 122$ MET-min/wk, $\mathrm{p}=0.001)$, and total PA $(925 \pm 587 \mathrm{MET}-$ $\mathrm{min} / \mathrm{wk}, \mathrm{p}=0.12$ ) were higher in the $\mathrm{C}$ group. A significant overall MANOVA time $(\mathrm{p}=0.001)$ and diet $(\mathrm{p}=0.01)$ effect was seen in body composition results. Univariate analysis revealed that both groups lost a similar amount of weight (C $-2.4 \pm 2.1,-4.4 \pm 3.6,-4.9 \pm 4.0$; W $-2.7 \pm 1.3$, $-5.3 \pm 2.4,-6.2 \pm 4.1 \mathrm{~kg}, \mathrm{p}=0.31)$. However, fat mass loss (C $-3.9 \pm 5.5,-4.6 \pm 5.3,-6.4 \pm 5.9$; W $-0.4 \pm 5.7,-2.1 \pm 6.7$, $-2.9 \pm 7.8 \mathrm{~kg}, \mathrm{p}=0.09)$ and reductions in percent body fat (C - $3.3 \pm 5.2,-3.2 \pm 4.6,-4.7 \pm 5.4$; W $0.6 \pm 6.7,-0.6 \pm 8.3$, $\left.-1.4 \pm 8.1 \%, \mathrm{p}_{q}=0.054\right)$ tended to be greater in the $C$ group while fat free mass was increased in the $C$ while decreasing in the W group (C $1.5 \pm 4.3,0.5 \pm 3.7,1.3 \pm 4.0$; W $-1.8 \pm 5.4,-2.4 \pm 5.8,-2.5 \pm 5.1 \mathrm{~kg}, \mathrm{p}=0.01)$. REE values 
increased over time in both groups and were non-significantly higher in the $C$ group $(C 0.9 \pm 2.2,1.4 \pm 2.3,1.3 \pm 1.9$; W $0.6 \pm 2.0,0.7 \pm 2.0,0.6 \pm 2.3 \mathrm{kcals} / \mathrm{kg} / \mathrm{d}, \mathrm{p}=0.19$ ).

\section{Conclusion}

Results indicate that 16-wks of participation in the C program that involved a more structured meal plan based diet and supervised exercise program promoted more favorable changes in body composition than participation in the $\mathrm{W}$ program that involved adherence to a point based diet, weekly counseling, and encouragement to increase physical activity.

\section{Funding}

Supported by Curves International (Waco, TX)

Published: 7 November 2011

doi:10.1186/1550-2783-8-S1-P4

Cite this article as: Mardock et al.: Comparative effectiveness of two popular weight loss programs in women I: body composition and resting energy expenditure. Journal of the International Society of Sports Nutrition 2011 8(Suppl 1):P4

Submit your next manuscript to BioMed Central and take full advantage of:

- Convenient online submission

- Thorough peer review

- No space constraints or color figure charges

- Immediate publication on acceptance

- Inclusion in PubMed, CAS, Scopus and Google Scholar

- Research which is freely available for redistribution

Submit your manuscript at www.biomedcentral.com/submit 